\title{
Brucite formation and dissolution in oceanic serpentinite
}

\section{F. Klein ${ }^{1 *}$, S.E. Humphris ${ }^{1}$, W. Bach ${ }^{2}$}

Abstract

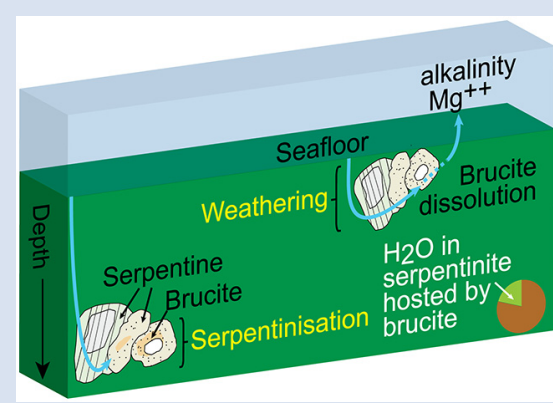

Brucite is an important, albeit elusive, hydrous mineral formed during serpentinisation, a vector of $\mathrm{Mg}$ from the mantle to seawater, and possibly a significant host of water in oceanic serpentinite. However, the abundance of brucite has not been quantified in oceanic serpentinite and its fate and related chemical fluxes remain uncertain. We used thermal analysis and confocal Raman spectroscopy to determine the abundance and distribution of brucite in serpentinite recovered by seafloor drilling $(n=48)$ and dredging $(\mathrm{n}=22)$. Almost all $(90 \%)$ of the drilled serpentinite samples contained brucite. The brucite contents increased with increasing extent of serpentinisation and constituted up to $15.6 \mathrm{wt}$. \% of the altered rock. In contrast, dredged serpentinites were devoid of brucite and lost $4.0 \mathrm{wt} . \% \mathrm{MgO}$ on average, which translates to an estimated average annual flux of $1.3 \times 10^{10}$ mole $\mathrm{Mg}$ and about $2 \times 10^{10}$ mole alkalinity during seafloor weathering of serpentinite globally. Our data suggest that, on average, brucite stores $\sim 20 \%$ of the water in unweathered serpentinite, making brucite one of the largest water carriers in slow and ultra-slow spreading oceanic lithosphere.

\section{Introduction}

Tectonic exhumation exposes peridotite to aqueous solutions and, because peridotite is unstable in the presence of $\mathrm{H}_{2} \mathrm{O}$ over a wide range of temperatures and pressures, it undergoes a series of dissolution-precipitation and redox reactions to form serpentinite. In addition to serpentine, serpentinites commonly contain other minerals in varying proportions, notably brucite, magnetite, talc, chlorite, and tremolite. Brucite is probably one of the most enigmatic minerals formed during serpentinisation. While it is believed to play a central role in modulating $\mathrm{SiO}_{2(a q)}$, $\mathrm{pH}$, and the generation of $\mathrm{H}_{2}$ (Klein et al., 2013), and is inferred to be a major carrier of water into subduction zones (Kawahara et al., 2016; Peters et al., 2020), few studies have detected brucite in oceanic serpentinite (e.g., Bach et al., 2004; Klein et al., 2009). In contrast to seemingly brucite-poor seafloor serpentinite, some continental exposures of serpentinite reveal up to 47 mole \% brucite (Hostetler et al., 1966). Indeed, seafloor serpentinites commonly show lower $\mathrm{MgO}$ and higher $\mathrm{SiO}_{2}$ concentrations than their continental counterparts, which Snow and Dick (1995) attributed to dissolution of brucite and incongruent dissolution of olivine during seafloor weathering. Alternatively, Malvoisin (2015) suggested that the generally lower $\mathrm{MgO}$ and higher $\mathrm{SiO}_{2}$ concentrations in seafloor serpentinites are due to the addition of $\mathrm{SiO}_{2}$ from gabbroic rocks, which would limit or even prevent brucite formation during serpentinisation. These models imply contrasting, large scale mass transfers between the oceanic lithosphere and seawater (Snow and Dick, 1995) and between mafic and ultramafic rocks within the oceanic lithosphere (Malvoisin, 2015). In this study, we examined the abundance of brucite in oceanic serpentinites.
We show that brucite is present in serpentinites recovered by drilling, but absent in serpentinites recovered by dredging directly from the seafloor. We then compare the measured and predicted abundances of brucite in serpentinite and discuss the significance of brucite formation and dissolution in serpentinised oceanic basement.

\section{Materials \& Methods}

We examined 22 partially to completely serpentinised, carbonatefree peridotites recovered by dredging and 48 recovered by scientific seafloor drilling. Samples were collected during cruises to the Mid-Cayman Rise, Southwest Indian Ridge, Gakkel Ridge, South American Antarctic Ridge, Mid-Atlantic Ridge, East Pacific Rise, Iberian Margin, Tyrrhenian Sea, and the Mariana forearc (Supplementary Information Table S-1). A description of these samples is provided elsewhere (Klein et al., 2009, 2014) and relevant features are summarised in the Supplementary Information.

We used thermogravimetry and differential scanning calorimetry (TGA-DSC) to quantify the abundances of serpentine and brucite, as well as the extents of serpentinisation. TGA-DSC is ideally suited for this purpose because dehydroxylation of serpentine and brucite involves mass loss and heat flow anomalies over distinct temperatures intervals (Lafay et al., 2012; Okamoto et al., 2011; Viti, 2010). Raman spectroscopy was performed for non-destructive, high resolution identification of minerals. Major element compositions of whole rock samples were determined by $\mathrm{X}$-ray fluorescence. A description of the analytical techniques used is provided in the Supplementary

\footnotetext{
1. Woods Hole Oceanographic Institution, 266 Woods Hole Rd, Woods Hole, MA 02543, USA

2. Department of Geosciences and MARUM, University of Bremen, Klagenfurter Str., 28359 Bremen, Germany

Corresponding author (email: fklein@whoi.edu)
} 
Information. To assess the stabilities of minerals in the system $\mathrm{MgO}-\mathrm{SiO}_{2}-\mathrm{H}_{2} \mathrm{O}$, equilibrium constants for their dissolution were calculated using SUPCRT92 (Johnson et al., 1992).

\section{Results}

TGA-DSC of serpentinites recovered by seafloor drilling and dredging yielded contrasting results (Figs. 1, S-1). With five exceptions (samples \# 173-1068A-22R-1W 30-33 cm, 153920B-1W-3W 64-66 cm, 153-920B-2R-1W 80-82 cm, 153920B-10R-1W, 82-86 cm, 153-920B-10R-2W 68-70 cm), drilled serpentinites exhibited significant mass loss between 250 and $450{ }^{\circ} \mathrm{C}$ with a maximum between 315 and $380^{\circ} \mathrm{C}$ accompanied by a marked endothermic heat flow anomaly. The mass loss and heat flow anomaly over this temperature interval are characteristic for dehydroxylation of Fe-bearing brucite (Okamoto et al., 2011), which was also identified by means of Raman spectroscopy on the basis of diagnostic Raman bands at $279 \mathrm{~cm}^{-1}$, $444 \mathrm{~cm}^{-1}$, and $3650 \mathrm{~cm}^{-1}$ in pseudomorphic textures after olivine (Fig. 2). The identification of brucite is corroborated by previously published electron microprobe analysis of the same samples (Klein et al., 2009, 2014). The mass loss from brucite due to the removal of water from its crystal structure was 1.24 to 4.60 wt. \% (average of 2.61 wt. \%). Considering that the approximate composition of brucite was $\mathrm{Mg}_{0.8} \mathrm{Fe}_{0.2}(\mathrm{OH})_{2}$ (Klein et al.,
2009 , 2014) the measured mass loss suggests brucite contents of 3.56 to 15.61 wt. \% (average of 8.58 wt. \%). Twenty two of the drilled samples $(n=48)$ exhibited additional mass loss around $280{ }^{\circ} \mathrm{C}$, which we attributed to dehydroxylation of the layered double hydroxide iowaite $\left(\mathrm{Mg}_{6} \mathrm{Fe}_{2} \mathrm{Cl}_{2}(\mathrm{OH})_{16}\right)$. The presence of iowaite was also indicated by Raman spectroscopy based on a strong Raman band at $527 \mathrm{~cm}^{-1}$. Hyperspectral Raman maps suggested that iowaite occurs in mesh texture where it replaces brucite (Fig. 2). To assess the total amount of brucite formed during serpentinisation, we included any mass loss from dehydroxylation of minor iowaite (i.e. $>250^{\circ} \mathrm{C}$ ) to brucite. This is justified because the molar ratio of $(\mathrm{Mg}+\mathrm{Fe}) / \mathrm{OH}$ in brucite and iowaite is 0.5 , and iowaite formed at the expense of brucite likely without significantly changing its $\mathrm{Mg} / \mathrm{Fe}$ ratio.

In contrast to drilled serpentinites, dredged serpentinites showed much smaller mass loss between 250 and $450{ }^{\circ} \mathrm{C}$ and no discernible heat flow anomaly over this temperature interval (Figs. 1, S-1, Table S-1). Hence, these samples do not contain brucite or iowaite in detectable amounts, i.e. they contain less than 0.4 wt. \% brucite. A marked mass loss between 450 and $750{ }^{\circ} \mathrm{C}$ in conjunction with pronounced endothermic heat flow anomalies are diagnostic of dehydroxylation of serpentine in drilled and dredged serpentinites (Viti, 2010). Raman spectroscopy suggested that most samples are dominated by lizardite with additional chrysotile. However, samples from the Mariana (a) Recovered by seafloor drilling

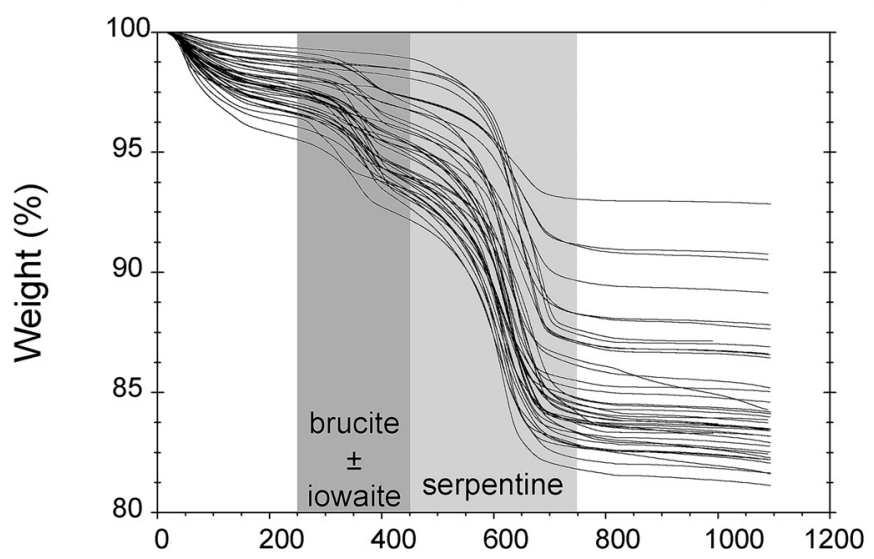

(b)

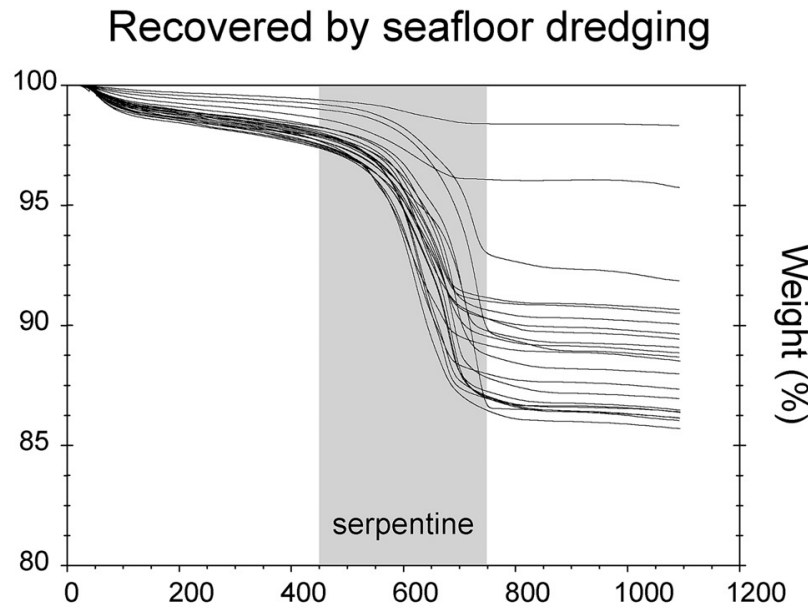

(c)

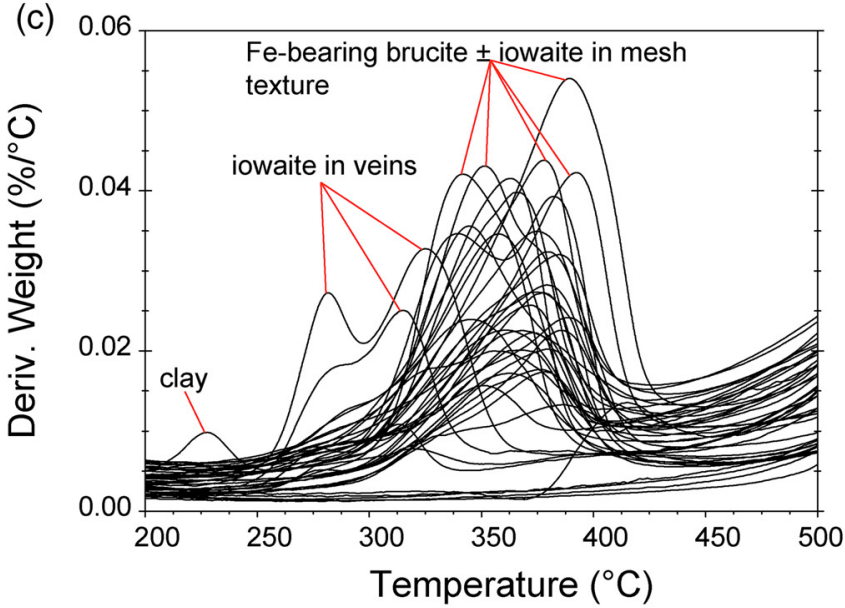

(d)

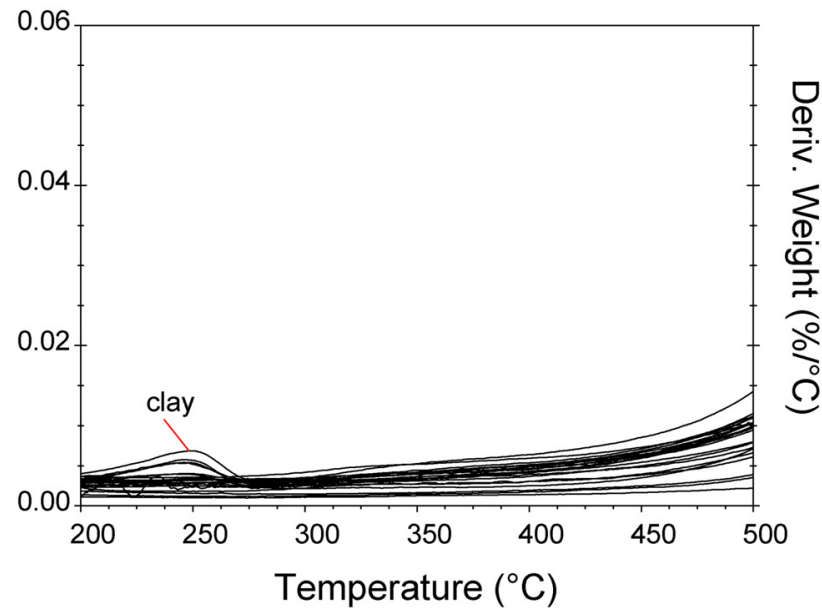

Figure 1 Thermal analysis of drilled $(a, c)$ and dredged $(b, d)$ serpentinites. Upper panels show the decrease in sample mass with temperature. Shading indicates mass loss via dehydroxylation of brucite \pm iowaite (dark grey) and serpentine (grey). Lower panels show first derivative (deriv.) of mass loss between 200 and $500^{\circ} \mathrm{C}$. Dehydroxylation of brucite( \pm iowaite) is apparent in drilled samples but not in dredged samples. 


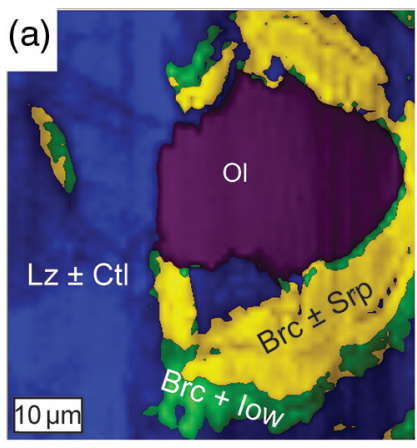

(c)
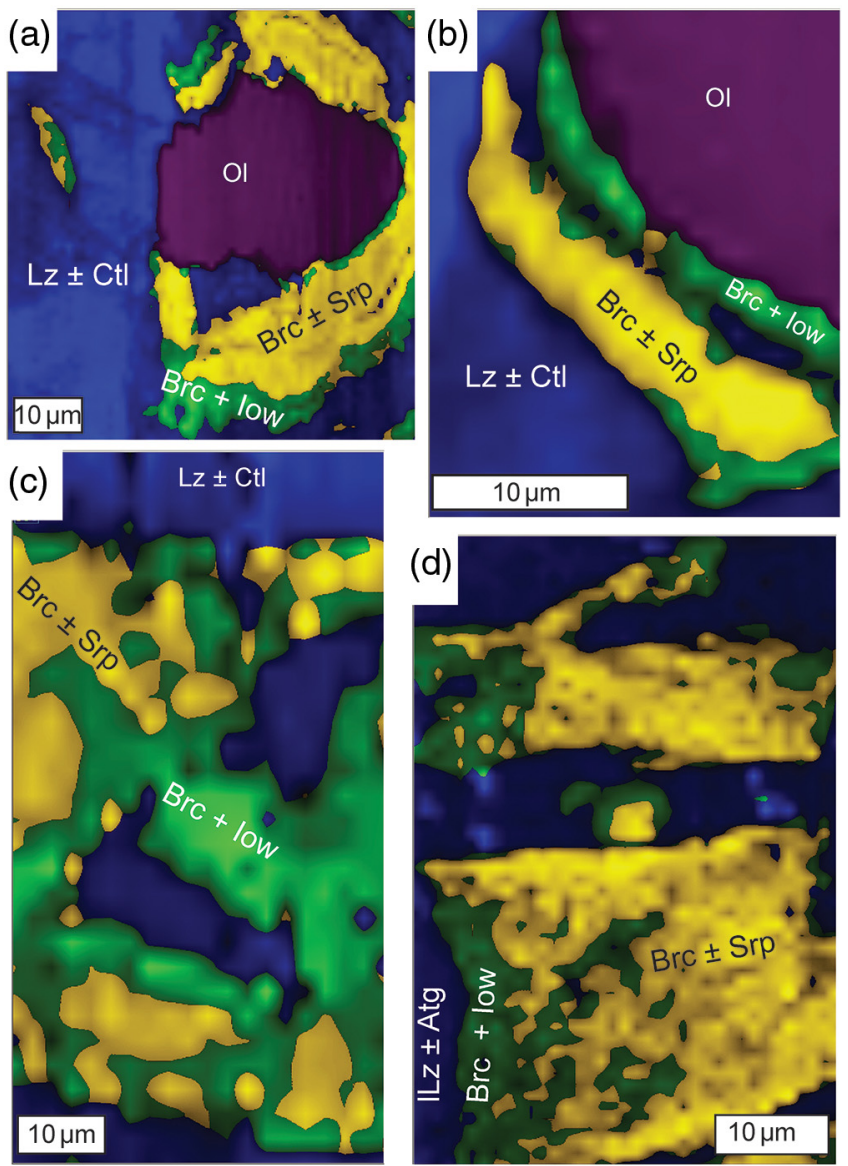

Figure 2 Hyperspectral Raman maps of brucite and serpentine in mesh texture in drilled samples. Some of the brucite is replaced by iowaite. Brucite and iowaite are intergrown with minor amounts of serpentine. (a) Sample 895D-3R-1W 64-66 cm. (b) Sample 1274A3R1 111-120 cm. (c) Sample 1068A-24R-2W 56-59 cm. (d) 779A-03R$1 \mathrm{~W}, 26-28 \mathrm{~cm}$.

forearc (ODP Leg 125) also contained antigorite, which was reflected by slightly higher dehydroxylation temperatures when compared with lizardite and chrysotile. The mass loss attributed to the removal of water from the crystal structure of serpentine was 4.24 to 11.64 wt. \% (average of 9.8 wt. \%) in drilled samples, consistent with incomplete serpentinisation and the presence of brucite in these samples. Together, serpentine and brucite in partially to completely serpentinised peridotite examined here contain 5.88 to 14.19 wt. \% water (average of 12.22 wt. \%). Of the total water content in unweathered serpentinite, on average, $80.28 \%$ is hosted by serpentine and $19.71 \%$ by brucite. In dredged samples, mass loss attributable to water removal from serpentine was 1.0 to $11.2 \mathrm{wt}$. \% (average of $8.1 \mathrm{wt}$ \%). Here, any mass loss lower than the expected $\sim 12.5$ wt. \% for pure serpentine is chiefly due to incomplete serpentinisation. Additional mass loss at temperatures lower than $250^{\circ} \mathrm{C}$ is related to removal of adsorbed water, destabilisation of clay minerals, or loss of interlayer water molecules in iowaite (Fig. 1).

\section{Discussion}

Brucite formation during serpentinisation. Brucite is present in $90 \%$ of the drilled serpentinites we examined (Figs. 1, S-1, Table S-1). It occurs together with serpentine in mesh texture and veins suggesting it formed at the expense of olivine under static conditions (Fig. 2). While brucite contents of serpentinites are variable, they increase with increasing whole rock water contents and with increasing whole rock $\mathrm{Mg} / \mathrm{Si}$ ratios (Fig. 3). Since drilled samples examined in this study show no evidence of extensive Si metasomatism (Fig. S-2), our results point to protolith composition and the extent of alteration as the primary controls on brucite contents in serpentinised peridotites. Previous studies using closed system thermodynamic equilibrium models predicted the effect of the protolith olivine/pyroxene ratio on the abundance of brucite in serpentinite (Klein et al., 2009, 2013; Malvoisin, 2015). Models for serpentinisation of pure olivine $\left(\mathrm{Mg}_{1.8} \mathrm{Fe}_{0.2} \mathrm{SiO}_{4}\right)$ by heated seawater predicted brucite contents ranging from 16.3 to $17.4 \mathrm{wt}$. \% (or 46 to 49 mole \%) between 250 and $150{ }^{\circ} \mathrm{C}$, respectively, i.e. the temperature interval where much of seafloor serpentinisation takes place (Klein et al., 2013, 2014). For comparison, complete serpentinisation of dunite produced 15.6 wt. \% brucite (Fig. 3, Table S-1). With increasing

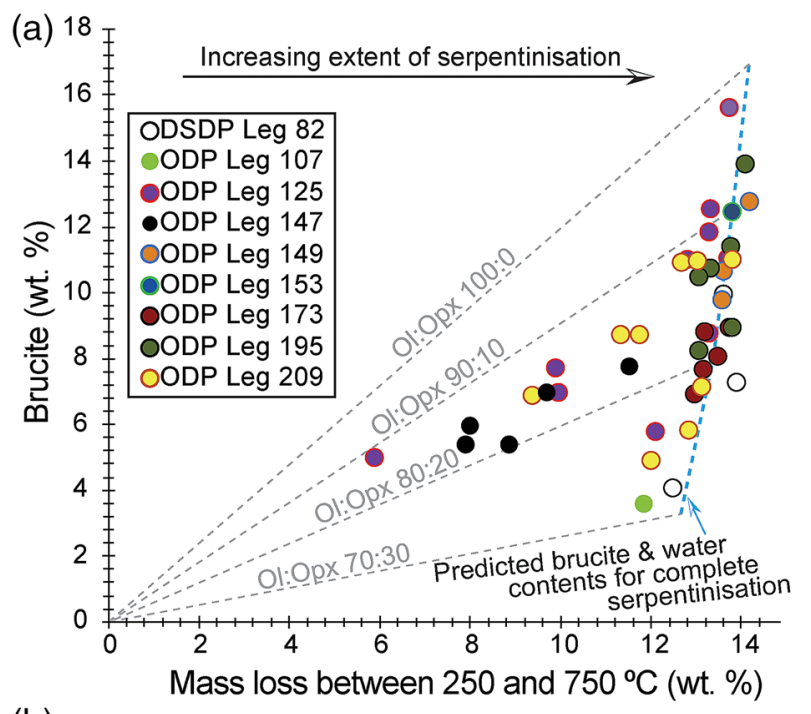

(b)

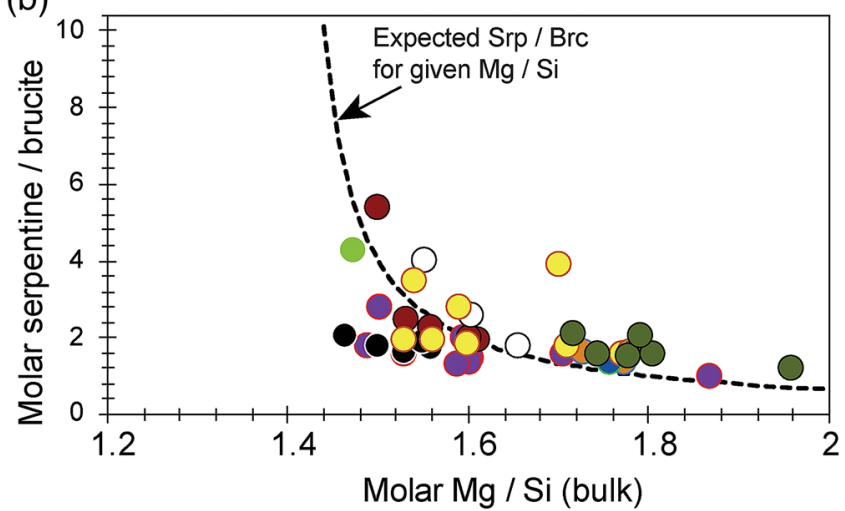

Figure 3 (a) Calculated brucite contents as a function of water content in serpentinite as derived from thermal analysis in comparison to brucite and water contents for serpentinisation of rocks with distinct modal proportions of olivine and orthopyroxene predicted from thermodynamic models (Klein et al., 2013). Note that the trajectories (grey dashed lines) point to averages of predicted brucite contents for complete serpentinisation (blue dashed line) of ultramafic rocks between 250 and $150^{\circ} \mathrm{C}$. They do not imply that the amounts of brucite increase linearly with the extent of serpentinisation. (b) Molar serpentine/brucite ratios in serpentinite as a function of molar Mg/Si ratios of whole rock samples. Molar serpentine/brucite ratios derived from thermal analysis are close to expected ratios for given molar Mg/Si ratios (dashed line) suggesting $\mathrm{Mg}$ and Si was conserved during serpentinisation. Only samples that showed evidence for brucite from thermal analysis are included. 
orthopyroxene content of the protolith, the modelled brucite contents for serpentinisation decreased due to the overall decreased $\mathrm{Mg} / \mathrm{Si}$ ratios. Harzburgite with 20 vol. \% orthopyroxene was predicted to yield 7.6 to 8.2 wt. \% brucite (or 26 to 28 mole \%) between 250 and $150{ }^{\circ} \mathrm{C}$, while serpentinisation of harzburgite with $30 \mathrm{vol}$. \% orthopyroxene would yield 3.0 to $3.5 \mathrm{wt}$. \% (12 to 14 mole \%) brucite over the same temperature range (Klein et al., 2013). Drilled serpentinites contained 3.56 wt. \% (or 14 mole \%) brucite or more, and 8.58 wt. \% (29 mole \%) on average. If serpentinisation was quasi-isochemical with respect to $\mathrm{Mg}$, $\mathrm{Fe}$, and $\mathrm{Si}$, their protoliths would have contained approximately $30 \mathrm{vol} . \%$ orthopyroxene or less and $20 \mathrm{vol}$. \% orthopyroxene on average. Independent estimates from point counting of serpentinised abyssal peridotite (Michael and Bonatti, 1985; Dick, 1989; Snow and Dick, 1995; Ohara et al., 2002) corroborate this estimate with an average orthopyroxene content of 20.8 vol. \%. In general, therefore, the range in brucite contents of fully serpentinised peridotites that were recovered by seafloor drilling (Figs. 1, 3) can be explained by variations of the initial olivine/ orthopyroxene ratio of the peridotite protolith.

Brucite dissolution during weathering. None of the dredged serpentinites examined here contain brucite or iowaite (Figs. 1, S-1). The lack of these minerals may be due to the addition of Si during serpentinisation. However, this would require that dredged serpentinite is affected by $\mathrm{Si}$ metasomatism whereas drilled serpentinite is not, an unlikely scenario. It has long been established that seawater is undersaturated with respect to brucite (Fig. 4; Nesbitt and Bricker, 1978). Consequently, serpentinites exposed to seawater on the seafloor for periods of time sufficient for low temperature weathering to occur are free of brucite - as our study demonstrates.

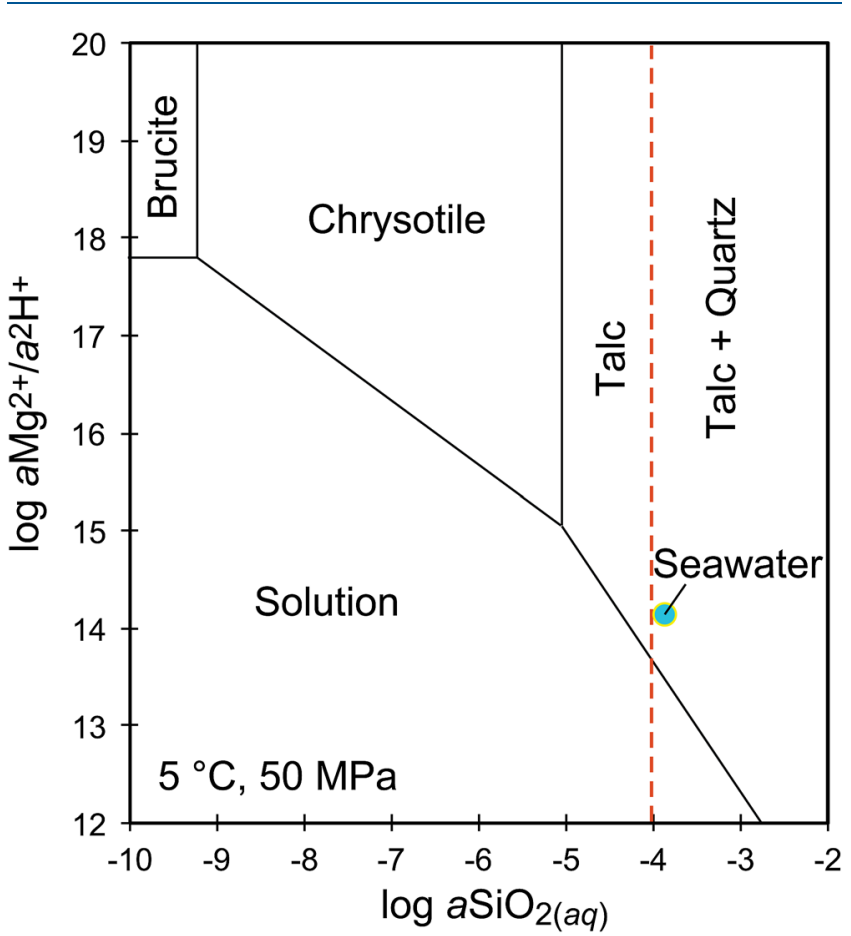

Figure 4 Activity-activity diagram depicting the stability fields of phases in the system MgO-SiO ${ }_{2}-\mathrm{H}_{2} \mathrm{O}$ at $5{ }^{\circ} \mathrm{C}$ and $50 \mathrm{MPa}$. Brucite is stable only at low activities (a) of $\mathrm{H}^{+}$(i.e. high pH) and $\mathrm{SiO}_{2(a q)}$, and grossly undersaturated in seawater. The red dashed line indicates the solubility of quartz. For simplicity, only $\mathrm{Mg}$ end members are illustrated and the water activity is assumed to be unity. Equilibrium constants were calculated using SUPCRT92 (Johnson et al., 1992).
While drilled serpentinites examined in this study do contain brucite, it is conceivable that seafloor weathering penetrates deeper into the subseafloor and dissolves brucite as the plate matures. In serpentinised dunite from ODP Site 1271 south of the $15^{\circ} 20^{\prime} \mathrm{N}$ Fracture Zone on the Mid-Atlantic Ridge, brucite is missing in the topmost core sections, but is abundant (10-15 vol. \%) in serpentinite from $>10 \mathrm{~m}$ sub-seafloor depth (Bach et al., 2004). The basement at Site 1271 was exposed about 1.5 Ma (Bach et al., 2011), suggesting that the brucite dissolution front propagated downward at a rate of $<10 \mathrm{~m}$ per Myr. If we assume that $5 \%$ (Carlson, 2001) of the seafloor in the Arctic, Atlantic, and Indian Oceans consists of serpentinite $\left(\sim 8,562,550 \mathrm{~km}^{2}\right)$, and that weathering leads to quantitative dissolution of brucite in the uppermost $100 \mathrm{~m}$ (i.e. in $856,255 \mathrm{~km}^{3}$ ) with a 4.0 wt. \% $\mathrm{MgO}$ loss on average (assuming serpentinite contains 8.58 wt. \% brucite), we calculate a $\mathrm{MgO}$ mass of $\sim 9 \times 10^{19} \mathrm{~g}$ transferred from the lithosphere to the ocean since the breakup of Pangaea, circa 175 million years ago. This would translate to an average flux of $\mathrm{MgO}$ of $\sim 5 \times 10^{11} \mathrm{~g} / \mathrm{yr}\left(\sim 1 \times 10^{10}\right.$ $\mathrm{mol} / \mathrm{yr}$ ). An upper estimate, where the seafloor of oceanic lithosphere accreted at slow and ultra-slow spreading ridges contains $25 \%$ serpentinite and the depth of weathering is $200 \mathrm{~m}$ would result in an average annual $\mathrm{MgO}$ flux of $\sim 5 \times 10^{12} \mathrm{~g} / \mathrm{yr}\left(\sim 1 \times 10^{11}\right.$ $\mathrm{mol} / \mathrm{yr})$. These fluxes are significant, but noticeably smaller than the continental runoff flux of $5 \times 10^{12} \mathrm{~mol} / \mathrm{yr}$ (e.g., Spencer and Hardie, 1990). With an approximate composition of $\mathrm{Mg}_{0.8} \mathrm{Fe}_{0.2}(\mathrm{OH})_{2}$, the potential loss of $\mathrm{FeO}$ from dissolution of brucite is 1.8 wt. \% on average. Much of this Fe may get oxidised and remain within the rock as ferric (oxyhydr)oxide alongside carbonate (Jöns et al., 2017; Templeton and Ellison, 2020). Each mole of brucite that dissolves adds two moles of alkalinity to the oceans, which will facilitate the sequestration of $\mathrm{CO}_{2}$ in the seabed. Complete oxidation and precipitation of $\mathrm{Fe}^{2+}$, which is also released when brucite dissolves, will add 0.4 moles $\mathrm{H}^{+}$ per mole $\mathrm{Mg}_{0.8} \mathrm{Fe}_{0.2}(\mathrm{OH})_{2}$, so the net alkalinity production per mole brucite dissolving is 1.6 moles. Hence, a net alkalinity flux on the order of $10^{11} \mathrm{~mol} / \mathrm{yr}$ can be expected. The related $\mathrm{CO}_{2}$ sink flux should be of similar magnitude, which is small (but perhaps not insignificant) compared to an annual oceanic outgassing flux of $2 \times 10^{12}$ mole $\mathrm{CO}_{2}$ (Marty and Tolstikhin, 1998).

\section{Conclusions}

Brucite in oceanic unweathered serpentinite recovered by drilling is common and widespread. This is at odds with the notion that oceanic serpentinite is brucite-poor, which resulted from a sampling bias toward dredged rocks that had undergone weathering. Brucite dissolution during weathering releases $\mathrm{Mg}$; however, the resulting fluxes are small compared with the riverine input. If brucite dissolution in old ultramafic basement reached as deep as $200 \mathrm{~m}$, then as much as $5 \%$ of the $\mathrm{CO}_{2}$ outgassing at mid-ocean ridges could be compensated by the related enhancement of alkalinity. Iron released via brucite dissolution is rapidly oxidised and largely conserved within the rock. Dissolution of olivine is an additional source of $\mathrm{Mg}$ and alkalinity to the oceans, but it is uncertain how much of that released flux is consumed by reverse weathering reactions.

The average brucite contents of unweathered serpentinites are close to those predicted from simple thermodynamic equilibrium models assuming primary mineral abundances characteristic of typical oceanic peridotite. Hence, the brucite contents of serpentinite examined in this study can be entirely explained by variations in the olivine/orthopyroxene ratio of the peridotite protolith. This finding also suggests that $\mathrm{Mg}$, Fe, and $\mathrm{Si}$ are largely conserved during serpentinisation. The abundance of brucite determined here underscores the previously 
suggested importance of brucite in affecting $a \mathrm{H}_{2(a q)}, a \mathrm{SiO}_{2(a q)}$ and the $\mathrm{pH}$ of oceanic serpentinisation systems. Notably, brucite hosts approximately $20 \%$ of the water in unweathered serpentinite and, therefore, likely represents an important carrier of water into subduction zones.

\section{Acknowledgements}

We greatly appreciate constructive comments by B. Tutolo and an anonymous reviewer, as well as editorial handling by S. Opfergelt. Support for this project was provided by the Independent Research \& Development Program at Woods Hole Oceanographic Institution, the US National Science Foundation (NSF Award \# 1059534 and 9986135), and the Special Priority Program 1144 of the German Science Foundation (BA 1605/1-1 and BA 1605/1-2). This research would not have been possible without samples supplied by the Ocean Drilling Program and the Seafloor Samples Laboratory at WHOI.

Editor: Sophie Opfergelt

\section{Additional Information}

Supplementary Information accompanies this letter at https:// www.geochemicalperspectivesletters.org/article2035.

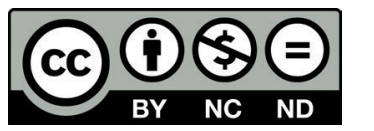

(C) 2020 The Authors. This work is distributed under the Creative Commons Attribution NonCommercial No-Derivatives 4.0 License, which permits unrestricted distribution provided the original author and source are credited. The material may not be adapted (remixed, transformed or built upon) or used for commercial purposes without written permission from the author. Additional information is available at http://www. geochemicalperspectivesletters.org/copyright-and-permissions.

Cite this letter as: Klein, F., Humphris, S.E., Bach, W. (2020) Brucite formation and dissolution in oceanic serpentinite. Geochem. Persp. Let. 16, 1-5.

\section{References}

Bach, W., Garrido, C.J., Harvey, J., Paulick, H., Rosner, M. (2004) Seawaterperidotite interactions - First insights from ODP Leg 209, MAR $15^{\circ}$ N. Geochemistry, Geophysics, Geosystems 5, Q09F26, doi: 10.1029/ 2004 GC000744.

Bach, W., Rosner, M., Jöns, N., Rausch, S., Robinson, L.F, Paulick, H., Erzinger, J. (2011) Carbonate veins trace seawater circulation during exhumation and uplift of mantle rock: Results from ODP Leg 209. Earth and Planetary Science Letters 311, 242-252.

CARLSON, R.L. (2001) The abundance of ultramafic rocks in Atlantic Ocean crust Geophysical Journal International 144, 37-48.

Dick, H.J.B. (1989) Abyssal peridotites, very slow spreading ridges and ocean ridge magmatism. In: SAUNDERS, A.D., NorRY, M.J. (Eds) Magmatism in the Ocean Basins. Blackwell, Oxford, 71-105.

Hostetler, P.B., Coleman, R.G., Mumpton, F.A., Evans, B.W. (1966) Brucite in alpine serpentinites. American Mineralogist 51, 75-98.

Johnson, J.W., OelKers, E.H., Helgeson, H.C. (1992) SUPCRT92: A software package for calculating the standard molal thermodynamic properties of minerals, gases, aqueous species, and reactions from 1-5000 bars and 0-1000 C. Computers $\mathcal{E}$ Geosciences 18, 899-947.

JÖNS, N., KAHL, W.-A., BACH, W. (2017) Reaction-induced porosity and onset of low-temperature carbonation in abyssal peridotites: Insights from 3D high-resolution microtomography. Lithos 268-271, 274-284.

Kawahara, H., Endo, S., Wallis, S.R., Nagaya, T., Mori, H., Asahara, Y. (2016) Brucite as an important phase of the shallow mantle wedge: Evidence from the Shiraga unit of the Sanbagawa subduction zone, SW Japan. Lithos 254255, 53-66.
Klein, F., Bach, W., Jöns, N., McCollom, T., Moskowitz, B., Berquó, T. (2009) Iron partitioning and hydrogen generation during serpentinization of abyssal peridotites from $15^{\circ} \mathrm{N}$ on the Mid-Atlantic Ridge. Geochimica et Cosmochimica Acta 73, 6868-6893.

KLeIN, F., BaCH, W., McCollom, T.M. (2013) Compositional controls on hydrogen generation during serpentinization of ultramafic rocks. Lithos 178, 55-69.

Klein, F., Bach, W., Humphris, S.E., Kahl, W.-A., JÖNS, N., MosKowitz, B., BERquó, T.S. (2014) Magnetite in seafloor serpentinite - Some like it hot. Geology 42, 135-138.

Lafay, R., Montes-Hernandez, G., Janots, E., Chiriac, R., Findling, N., Toche, F. (2012) Mineral replacement rate of olivine by chrysotile and brucite under high alkaline conditions. Journal of Crystal Growth 347, 62-72.

Malvoisin, B. (2015) Mass transfer in the oceanic lithosphere: Serpentinization is not isochemical. Earth and Planetary Science Letters 430, 75-85.

Marty, B., TolstiKhin, I.N. (1998) $\mathrm{CO}_{2}$ fluxes from mid-ocean ridges, arcs and plumes. Chemical Geology 145, 233-248.

Michael, P.J., Bonatti, E. (1985) Peridotite composition from the North Atlantic: regional and tectonic variations and implications for partial melting. Earth and Planetary Science Letters 73, 91-104

NeSBITT, H.W., BRICKER, O.P. (1978) Low temperature alteration processes affecting ultramafic bodies. Geochimica et Cosmochimica Acta 42, 403-409.

Ohara, Y., Stern, R.J., IshiI, T., Yurimoto, H., YamaZaKi, T. (2002) Peridotites from the Mariana Trough: first look at the mantle beneath an active back-arc basin. Contributions to Mineralogy and Petrology 143, 1-18.

Okamoto, A., Ogasawara, Y., Ogawa, Y., Tsuchiya, N. (2011) Progress of hydration reactions in olivine- $\mathrm{H}_{2} \mathrm{O}$ and orthopyroxenite $-\mathrm{H}_{2} \mathrm{O}$ systems at $250{ }^{\circ} \mathrm{C}$ and vapor-saturated pressure. Chemical Geology 289, 245-255.

Peters, D., PetTKe, T., John, T., ScambelluRi, M. (2020) The role of brucite in water and element cycling during serpentinite subduction - Insights from Erro Tobbio (Liguria, Italy). Lithos 360-361, 105431.

Snow, J.E., Dick, H.J.B. (1995) Pervasive magnesium loss by marine weathering of peridotite. Geochimica et Cosmochimica Acta 59, 4219-4235.

SPenCer, R.J., HARdie, L.A. (1990) Control of seawater composition by mixing of river waters and mid-ocean ridge hydrothermal brines. In: SPENCER, R.J., Chou, I.-M. (Eds). Fluid-Mineral Interactions: A Tribute to H.P. Eugster. The Geochemical Society, Special Publication No. 2, 409-419.

Templeton, A.S., ElLison, E.T. (2020) Formation and loss of metastable brucite: does $\mathrm{Fe}(\mathrm{II})$-bearing brucite support microbial activity in serpentinizing ecosystems? Philosophical Transactions of the Royal Society A: Mathematical, Physical and Engineering Sciences 378, 20180423.

VITI, C. (2010) Serpentine minerals discrimination by thermal analysis. American Mineralogist 95, 631-638 